\title{
MONUMENTS OF HISTORY AND CULTURE IN THE SYSTEM OF STATE-CONFESSIONAL INTERACTION IN THE POST-SOVIET PERIOD (ON THE EXAMPLE OF KARACHAY-CHERKESSIA)
}

\author{
(C) Natalya V. Kratova
}

\author{
Karachay-Cherkess Institute of Humanitarian Research under the Government of the KCR, \\ Cherkessk, Karachay-Cherkess Republic, Russian Federation \\ nvkratova@mail.ru
}

\begin{abstract}
This article is devoted to an important, very complex and controversial issue in the sphere of stateconfessional relations - the return to religious organizations of once nationalized religious buildings and other religious property. In the Russian Federation, unlike some other post-Soviet countries, they categorically refused to restitution of nationalized property, however, they made some concessions regarding religious organizations, recognizing the possibility of returning buildings and religious utensils. Several government decrees were issued that regulated this process, and a Commission on Religious Associations under the Government of the Russian Federation was created specifically to coordinate these issues. In 2010, Federal Law No. 327-FZ "On the transfer of religious property owned by state or municipal property" to religious organizations was issued, in accordance with which, in the case of official treatment by a religious organization, any religious property is subject to transfer, regardless of the form of ownership. However, to put into practice the right granted by the state turned out to be quite difficult. A large number of problems arose, which were difficult to solve. As a rule, religious buildings often housed museums or other institutions that needed to be translated somewhere. The question arose about the safety of the property being transferred, which could inevitably suffer from regular use. Under the conditions of Karachay-Cherkessia, the church's attempts to return the temple complexes of the 10th century met with stiff resistance not only from the museum management, but also from the public, who considered the monuments, primarily, as the cultural value of their people. This article shows how this problem was solved in the KCR in the post-Soviet period. The article is based on documents from the archive of the Authorized Head of the KCR on relations with religious organizations, copies of which were kindly transferred to the author.
\end{abstract}

Key words: state-confessional relations, state-confessional politics, Karachay-Cherkess Republic, recent history of Russia, restitution of church property, Russian Orthodox Church.

\section{[Н.В. Кратова Памятники истории и культуры в системе государственно-конфессионального взаимодействия в постсоветский период (на примере Карачаево-Черкесии)]}

Настоящая статья посвящена важному, весьма сложному и неоднозначному вопросу сфреры государственно-конфессиональных отношений - возвращению религиозным организациям некогда национализированных культовых зданий и другого имущества религиозного назначения. В Российской Федерации, в отличие от некоторых других стран постсоветского пространства, категорически отказались от проведения реституции национализированного имущества, однако в отношении религиозных организаций пошли на некоторые уступки, признав возможность возвращения зданий и утвари религиозного назначения. Вышло несколько правительственных постановлений, регламентировавших этой процесс, специально для координации этих вопросов была создана Комиссия по вопросам религиозных объединений при Правительстве РФ. В 2010 году был издан Федеральный закон № 327-Ф3 «О передаче религиозным организациям имущества религиозного назначения, находящегося в государственной или муниципальной собственности», в соответствии с которым в случае официального обращения религиозной организации передаче подлежат любые объекты религиозного назначения, независимо от формы собственности. Однако реализовать на практике предоставленное государством право оказалось совсем непросто. Возникло большое количество проблем, решить которые было достаточно трудно. Как правило, в культовых зданиях часто располагались музеи либо иные учреждения, которые нужно было куда-то переводить. Вставал и вопрос о сохранности передаваемого имущества, которое неизбежно могло пострадать от регулярного использования. В условиях Карачаево-Черкесии попытки церкви вернуть храмовые комплексы $X$ века натолкнулись на жесткое сопротивление не только музейного руководства, но и общественности, рассматривавшей памятники прежде всего как культурную ценность своего народа. В настоящей статье показано, как решалась эта проблема в КЧР в постсоветский период. Статья основана 
на документах из архива Уполномоченного Главы КЧР по связям с религиозными организациями, копии которых были любезно переданы автору.

Ключевые слова: Государственно-конфессиональные отношения, государственноконфессиональная политика, Карачаево-Черкесская Республика, новейшая история России, реституция церковной собственности, Русская Православная Церковь.

Natalya V. Kratova - Ph.D. in History, Associate Professor, Karachay-Cherkess Institute of Humanitarian Research under the Government of the KCR, Cherkessk, Karachay-Cherkess Republic, Russian Federation.

Кратова Наталья Васильевна - кандидат исторических наук, доцент, Карачаево-Черкесский институт гуманитарных исследований при Правительстве КЧР, г. Черкесск, Карачаево-Черкесская республика, Российская Федерация.

An important place in state-confessional relations in the post-Soviet period was occupied by the problem of the return to religious organizations of nationalized religious buildings and religious property.

The need to restore justice was recognized by the Soviet government. The possibility of transferring state property to religious organizations was discussed in Art. 17 of the Law of the USSR of 01.10.1990 No. 1689-I "On Freedom of Conscience and Religious Organizations" and Art. 26 of the Law of the RSFSR of 10.25.90 No. 267-I "On Freedom of Religion". On December 29, 1990, a resolution of the Council of Ministers of the USSR "On the Procedure for Transferring Religious Organizations into the Ownership of Religious Buildings, Structures, and Other Religious Property Owned by the State" was issued. This decree extended to religious organizations the procedure for transferring property that was in effect for public organizations, established by decree of the Council of Ministers of the USSR of October 16, 1979 No. 940 "On the Procedure for the Transfer of Enterprises, Associations, Organizations, Institutions, Buildings and Structures". The Council of Religions under the Council of Ministers of the USSR sent corresponding explanations to the regional executive committees on February 28, 1991. In turn, the Commissioner of the Council for KCAO (KarachayCherkess Autonomous Oblast) sent them to city and regional executive committees [19].

In accordance with this decree and these explanations, religious organizations had the preemptive right to transfer to them ownership or gratuitous use of religious buildings with an adjacent territory. The transfer was carried out by the local Councils of People's Deputies after approval by the state authorities for the protection of monuments on the basis of a statement by a religious organization. In the event that the property being transferred was a cultural monument, the conclusion of a protection agreement was envisaged.

The main object located on the territory of Karachay-Cherkessia, falling under the scope of this decree, was the temple complexes of the Karachay-Cherkess historical-cultural and natural museum-reserve.

Five temples of the 10th century (Sentinsky - near the village of Nizhny Teberda, Shoaninsky - near the village of K. Khetagurov and three temples - North, Middle and South - near the village of Nizhny-Arkhyz) are the oldest Christian churches in Russia.

In the 9th-13th centuries, on the territory of modern Karachay-Cherkessia, there was a large political and cultural center of the Alanian state, an ally of Byzantium, an outpost of eastern Christianity. It was here that the center of the Alan diocese was located. The cathedral was the Northern Church of the Nizhny Arkhyz complex (the bishop's chair was located in its altar).

At the end of the 19th century, the Holy Alexander Nevsky Monastery was created on the basis of these temples. At the beginning of the 20th century, the Transfiguration of the Savior Monastery was formed near the Senty Church. After the revolution, the monasteries were closed; their property was confiscated. 
In the Soviet period, various institutions were located on the territory of the monastery, the latter being the Arkhyz tourist base for children.

In 1988, the temples and buildings of the monastery became part of the KarachayCherkess historical-cultural and natural museum-reserve.

The issue of the return of the churches of the Russian Orthodox Church was first publicly raised in 1991. In June 1991, the Karachay-Cherkess Council of People's Deputies received an appeal from the All-Church Orthodox Youth Movement (VPMD) with a request to transfer the Nizhny Arkhyz temple complexes to the Stavropol-Baku Diocese, citing the need to preserve collapsing monuments of great importance for the Christian world [17]. In confirmation of the seriousness of intentions, the Russian Orthodox Church on the territory of Nizhny Arkhyz organized an International youth camp. Church initiative received the support of the Minister of Culture of the RSFSR (Russian Soviet Federative Socialist Republic) Yu.M. Solomina. Within 10 days, young believers from France and Belgium (21 people) cleared the territory of the former monastery [22].

November 6, 1991 Zelenchuk District Council of People's Deputies, supported the appeal of the Orthodox community of the village. Nizhny Arkhyz went on a petition to the Council of People's Deputies of the KCAO, the Council of Ministers of the RSFSR, the Presidium of the Supreme Council of the RSFSR and to the President of the RSFSR B.N. Yeltsin on the transfer of buildings and structures of the former Holy Alexander Nevsky Athos Monastery to the jurisdiction of the Orthodox community of the village. Nizhny Arkhyz, the rector of which at that time was the priest Victor Boyko [27].

The petition was based on Article 17 of the USSR Law "On Freedom of Conscience and Religious Organizations," which stipulated that local Councils of People's Deputies and state bodies may transfer religious buildings and other state-owned property to religious organizations for free or for free use.

The transfer was proposed to be implemented in stages. Initially, before February 1, 1992, the buildings and structures of the former Arkhyz children's camp site were to be transferred to the Nizhny Arkhyz community for worship at the Ilyinsky Church. In addition, until January 1, 1993 all the buildings and structures of the Karachay-Cherkess Museum-Reserve should be transferred to the restored monastery. The argument for the transfer was the lack of funds for the restoration and maintenance of the monuments and the willingness of the Russian Orthodox Church to take these costs upon itself.

The petition of the Zelenchuk regional council had no result. In 1992, the Metropolitan of Stavropol and Baku Gideon addressed the Deputy Prime Minister A.N. Shokhin, Head of the Administration of the KCAO V.I. Khubiev, Chairman of the Committee on Freedom of Conscience, Religion, Charity and Charity V.S. Polosinu [14]. The appeal contained a request to transfer to the Russian Orthodox Church the Southern and Middle Temples of the Nizhny Arkhyz Complex, the Senty Church and the buildings of the Preobrazhensky Monastery in Nizhnya Teberda, the Shoana Church and the buildings of the St. George Monastery near village named after Costa Khetagurova. In the treatment, the coexistence of the monastery and the museum was discussed.

No decision on the transfer was made, however, it was possible to attract the attention of the authorities. Correspondence has been preserved on the allocation of 340 million rubles from the federal budget "to support the Muslim and Orthodox communities of the republic" [10]. The result of this correspondence, unfortunately, is not known.

On April 23, 1993, Presidential Decree No. 281-rp "On the Transfer of Religious Buildings and Other Property to Religious Organizations" was issued. On April 30, a request from the Chairman of the Council of Ministers of the Russian Federation V.S. Chernomyrdina was sent to the Council of Ministers of the KCR. Chernomyrdin on the execution of the order of the President of the Russian Federation. May 13, 1993 addressed to the Deputy Prime Minister of the Russian Federation V.F. Shumeyko and Chairman of the Council of Ministers of the 
KCR V.I. Khubiev was sent a repeated request from His Grace Gideon for the transfer of temple complexes of the Russian Orthodox Church [15]

The Metropolitan's appeal caused a sharply negative reaction from the Karachai public. May 31 addressed to the Chairman of the Supreme Council of the KCR, V. Savelyev, and the Chairman of the Council of Ministers of the KCR, V.I. Khubiev was sent a letter signed by the Chairman of the Circassian branch of the Karachay Democratic Organization "Jamagat" K.I. Chomaev. The letter said about the inadmissibility of the transfer of churches to the Church because:

a) the churches have nothing to do with the Church, because they ceased to be churches / monasteries / for a thousand years;

b) are of fundamental importance to the KCR, since they are the oldest monuments of classical architecture in Russia;

c) are the original and inalienable property of the Karachai people;

d) it (the Stavropol diocese) can help their maintenance and restoration by their own means, by no means claiming to take them into property [20].

The leadership of the museum-reserve also reacted negatively to the possibility of transferring the temple complexes of the Church. July 30, 1993 in the name of V.S. Chernomyrdin was sent a letter signed by A.G. Ozova. The draft letter was prepared by the museum director M.O. Baychorova. The letter stated that the transfer of the Russian Orthodox Church complexes was not practical, one of the reasons was that "indigenous peoples evaluate this act as an infringement of their historical, cultural and spiritual interests." At the same time, it was stipulated that "the management of the Museum-Reserve will not obstruct visiting these unique monuments, including the clergy and believers" [18].

Commissioner for Relations with Religious Organizations N.G. Provatorov prepared an alternative draft response to Chernomyrdin, which proposed a compromise option for transferring museum property to the church [23]. So, the project proposed to transfer to the Karachay-Cherkess rural dean not the churches, but the buildings of the monastery of the late XIX - early XX centuries, which did not have cultural and historical values: a monastic ("brotherly") building, a dining room and an office near the Ilyinsky temple of the Nizhnearkhiz fortress; the refectory with the inner church, the dormitory with the inner church and the basement of the former Preobrazhensky nunnery near a. Nizhny Teberda, as well as church utensils from the museum. This project has not been implemented.

The result of the appeals was the corresponding instructions of the Government of the Russian Federation dated August 26 and November 16, 1993 to the State Property Committee of the Russian Federation. The result of the consideration of the issue was a letter from the Deputy Chairman of the State Property Committee of the Russian Federation O.Yu. Kachanova to the Council of Ministers of the KCR and the Zelenchuksky District Council of People's Deputies [13]. The federal center has taken a neutral position. It was recommended to interested parties "to find a solution on the basis of existing legislative acts of the Russian Federation taking into account regional interests". Referring to the existing practice of resolving such issues, it was proposed to conclude an agreement between the Museum-Reserve and the diocesan administration.

In accordance with the proposed scheme, in 1993 between the museum and the Orthodox community an agreement was signed on the use of the South (llyinsky) church. In 1994, after the address of the Dean of the Orthodox Churches Vasily Afonin to the Deputy Prime Minister of the Russian Federation, Chairman of the Commission on Religious Associations S.M. Shahrai [11], the agreement was supplemented with clauses on the possibility of providing the Orthodox community of the Northern Zelenchuksky temple for worship on holidays, and a modern building in the complex for non-public activities [24].

Thus, a compromise was reached, which allowed to translate the relations of the Orthodox community and the museum into the legal channel. The attempts of the Orthodox to re- 
turn to the discussion of the issue were unsuccessful, although the reasons were sufficient. On May 6, 1994, Decree of the Government of the Russian Federation No. 466 was adopted "On the Procedure for the Transfer to Religious Associations of Religious Buildings and Other Religious Property Related to Federal Property".

In 1995, Metropolitan Gideon sent a letter to the Chairman of the Council of Ministers of the KCR V.I. Khubiyev, in which the question of the transfer of temples was raised again [16]. The opinion of the bishop was completely correlated with the general Church position. In the definition of the Russian Orthodox Church Council on November 29, 1994 "On the Relations of the Church with the State and Secular Society in the Canonical Territory of the Moscow Patriarchate at the present time", the question was directly raised about the return to the canonical church structures of property nationalized in the post-revolutionary period and it was proposed to introduce a set of tax and customs preferences [30]. By this time, there was an experience of transferring to the Russian Orthodox Church, both individual religious buildings, and the joint use of museum complexes of the Moscow Kremlin, Novodevichy Convent, New Jerusalem. The Moscow Patriarchate entered into cooperation agreements with the Ministry of Defense of the Russian Federation, the Ministry of Education of the Russian Federation and the Ministry of Culture of the Russian Federation.

However, the republic insisted on the agreements reached in 1993. The letter of the bishop remained unanswered. The leadership position was communicated to Gideon through the diocesan secretary.

In 1995, by Decree of the President of the Russian Federation No. 176 of February 20, the Karachayev-Cherkess Museum-Reserve was included in the list of objects of historical and cultural heritage of federal (all-Russian) significance.

On October 25, 1997, a new agreement was signed between the museum and the Orthodox community of Nizhny Arkhyz on the preservation and use of a historical and cultural monument of religious designation. The agreement was accompanied by "Special Conditions", which stipulated, among other things, the possibility of one-time services in the Northern and Middle churches, as well as the Act of the technical condition of the Ilyinsky church and two houses transferred to the community [5].

In 2000, the issue of transferring temple complexes of the Russian Orthodox Church was again updated. On May 1, 2000, the museum's directorate demanded that the llyinsky Temple be vacated for restoration work. This caused concern of the Orthodox public. In July 2000, the Deputy of the National Assembly S.V. Zhilkin addressed to the President of the KCR with a proposal to secure the Ilyinsky Temple for unlimited and gratuitous use, transfer the Bratsk corps to the community, conclude an agreement between the Ministry of Culture of the Russian Federation and the Russian Orthodox Church on the joint use of temple complexes and create a Russian Christian humanitarian center on the basis of the Nizhny Arkhyz complex [7].

The proposed scheme, on the one hand, secured the possibility of using temples, both for liturgical and for cultural and educational purposes. The question of the reconstruction of the monastery was removed. Similar letters were sent to the Patriarch of Moscow and All Russia Alexy II, Metropolitan of Stavropol and Vladikavkaz Gideon, Minister of Culture of the Russian Federation.

The deputy initiative was supported by Metropolitan Gideon, who sent his request for the transfer of churches of the Russian Orthodox Church and the reconstruction of the monastery to the Minister of Justice of the Russian Federation Yu.Ya. Chayka, Minister of Culture of the Russian Federation M.E. Shvydko, President of the KCR V.M. Semenov.

The letters received by the President of the KCR were examined at the Ministry of Culture of the KCR and the Commissioner for Relations with Religious Organizations. On behalf of the Head of the Administration of the President of the KCR, two notes were prepared reflecting a different vision of the current situation [28]. 
The discussion was summarized at the meeting of the President of the KCR V.M. Semenov with representatives of the Russian Orthodox Church and the Ministry of Culture of the KCR on October 19, 2000. At the meeting, an agreement was reached on revising the agreement between the Museum-Reserve and the llya community, a decision was made to transfer the Brotherhood Corps, an order was given to prepare letters to the Ministry of Culture of Russia with support for the initiative of the diocese on the joint use of temple complexes and the creation of the Russian Christian Humanitarian Center on their basis [25].

The discussion of the problem and the decisions made received a wide response among the Karachai public. October 21, 2000, in the name of V.M. Semenov a letter was sent to the chairman of the Interregional Karachai Association "Alan" A.A. Katchiev, containing harsh criticism of the submitted projects [21]. Director of the Nizhny Arkhyz Branch of the Museum-Reserve U.Yu. Elkanov also categorically refused to comply with the agreements reached at the meeting of the President of the KCR.

In this situation, it was decided to consider the matter on a commission basis. January 18, 2001 at a meeting of the Commission under the President of the KCR on economic and property issues, chaired by the Vice President of the KCR, A.G. Lyashov decided to create a special commission to study the issue, headed by Deputy Chairman of the Government of the KCR, S. A. Mukhortovym. On February 6, 2001, the commission held a visiting meeting in the village. Nizhny Arkhyz, where the problem of the use of temples was comprehensively discussed with the participation of all interested parties [26]. The commission also received letters from the Republican Inspectorate for the Preservation of Monuments of History and Culture, which very critically evaluated the activities of the museum-reserve and its Lower Arkhyz branch [9]. Based on the results of the discussions, a conclusion was formulated and presented to the leadership of the republic, which reflected specific proposals aimed at improving the efficiency of the museum-reserve [8].

The results of the work of the special commission were discussed on March 20, 2001 at a meeting of the Commission on Economic and Property Issues. Most of the proposals of the special commission remained unclaimed. The transfer of churches to the Russian Orthodox Church was deemed inappropriate, the current procedure for using the Southern Church and two buildings by the Orthodox community was enshrined. The main result of the commission's work was a more thorough legal elaboration of an agreement of the use a church and museum premises by the Russian Orthodox Church [6].

The next aggravation of the situation around the temple complexes was caused by statements made by the bishop of Stavropol and Vladikavkaz Feofan (Ashurkov) during his study visit to the republic after being appointed to the Stavropol department in July 2003. On July 17, the Republic Day published his speech during a press conference held at the Republican Library on July 13 [4]. His Grace spoke rather harshly about the necessity of returning the churches of the Russian Orthodox Church. This position caused a wide public outcry. The answer was the publication in MK-Caucasus on October 1-8, 2003 of a lengthy open letter by Professor I.I. Aliyev, in which the claims of the Church were categorically denounced. The letter was widely circulated, sent to state authorities and to the Patriarchate [1].

This "discussion" was continued in 2009. On May 14, 2009, a meeting of the delegation of the Public Chamber of the Russian Federation with public organizations of the republic was held at the Government House of the KCR. I.I. Aliyev who took part in the meeting was at that time the deputy chairman of the KCR Government, spoke sharply about the actions of the Russian Orthodox Church to return the temples. The incident was perceived painfully by the Orthodox Slavic community. Dean Valentin Korneev, who was present at the meeting, left the meeting room and sent letters addressed to the President of the KCR B.S. Ebzeev and Plenipotentiary Representative of the President of the Russian Federation in the Southern Federal District V.V. Ustinov, in which he expressed concern about the negative attitude of 
I.I. Aliyev to the Russian Orthodox Church and its hierarchy [12]. Despite the intervention of the federal center, no official clarification was made.

The peak of tension came in 2010. On June 7, 2010, Patriarch of Moscow and All Russia Kirill sent a letter to the Prime Minister of the Russian Federation, Vladimir Putin, in which the question of the return of churches of the Russian Orthodox Church was again raised. In the State Duma of the Russian Federation, the preparation of the Federal Law "On the transfer of religious property owned by state or municipal property" to religious organizations has begun. This aroused great concern among politicians and public figures of the KarachayCherkess Republic. A group of deputies of the KCR People's Assembly submitted a draft appeal to V.V. Putin for consideration by the Republican Parliament, which categorically rejected the possibility of transferring churches to the ownership of the Russian Orthodox Church.

The important thing, from the point of view of opponents of the transfer of churches to the church, was the registration of complexes in the republican property [2]. From a legal point of view, this action did not make sense. According to the Federal Law N 327-FZ adopted on November 30, 2010 "On the Transfer to Religious Organizations of State-or MunicipalOwned Property for Religious Purpose", in case of official appeal to a religious organization, any religious objects are subject to transfer, regardless of the form of ownership. However, the removal of objects from federal ownership significantly reduced the possibility of obtaining funds from the federal budget for their restoration and maintenance, and also imposed corresponding obligations on the republican budget.

The end of 2010 and the beginning of 2011 were marked by resonant acts of vandalism. On the night of November 1, 2010, two Orthodox churches (Panteleimonovsky in Karachayevsk and the Martyr Barbara in the village of Ordzhonikidzevsky) were set on fire and the prayer house of the Evangelical Christian Baptists in Karachayevsk. On December 8, the Stella of St. Uastyrdzhi was destroyed. Six months later, on the morning of April 30, 2011, an arson of the Shoaninsky (St. George's) temple was committed [29]. It is difficult to say for sure how these actions were related to the dispute about the temples, but experts openly considered the issue of the transfer of temples to the church as a factor that destabilizes interethnic and interfaith relations. The acuteness of the debate unfolding under expert publications fully confirmed these fears [4]. At the domestic level, arson was perceived as a direct threat.

The constructive and balanced position of the new Head of the KCR R.B. Temrezov helped solve this difficult situation as well as of the head of the newly formed Pyatigorsk and Circassian diocese of Bishop Feofilakt. During his visit to the republic in March 2011, the bishop made an important, at the same time, unexpected for many statement about the absence of claims from the Russian Orthodox Church on the transfer of temple complexes to property. At the same time, the importance of using churches for their intended purpose was emphasized, without prejudice to their preservation. Mutual understanding on this issue was demonstrated both with the leadership of the republic and with the Muslim community. One of the statements on this topic was made during a meeting with the chairman of the Coordination Center for Muslims of the North Caucasus I. Berdiev. This position was reinforced during the official meeting of R.B. Temrezov with the Patriarch of Moscow and All Russia Kirill, which took place on April 4, 2012. Steps were taken to normalize relations with the leadership of the Museum-Reserve; a set of bishop vestments was presented to the museum as a gift.

In turn, the Head of the Republic Rashid Temrezov did everything possible to complete the construction of St. Nicholas Cathedral in the city of Cherkessk, for a year a church in the village Kavkazskiy, in the Nizhny Arkhyz the Cathedral of Christ the Savior as well as a staircase to the Face of Christ were built. Direct contacts with the diocesan bishop made it possible to quickly resolve all emerging issues. 
The result of such cooperation was the solution of an important problem. Preserving the temples in state ownership, public opinion was reassured. At the same time, it was ensured not only the legal stay of the Russian Orthodox Church near the ancient Christian holy places, but also the unhindered conduct of worship in these churches, which, in fact, the Orthodox sought. The influx of pilgrims increased significantly. Thousands of believers from the Southern and North Caucasian federal districts gathered for worships during the patronal feasts of ancient temples (Trinity, St. Elijah, St. George). This was largely facilitated by the appointment of Archimandrite Anthony (Skrynnikov), the former head priest of the Holy Assumption Alansky Monastery, who enjoys great authority among the believers of North Ossetia and the KCR.

In 2018, the temples were placed under the jurisdiction of a specially created institution i.e. the Karachay-Cherkess Republican State Budgetary Institution "Alan Ancient Christian Center in the North Caucasus" (director - Ahmad Kemalovich Erkenov), under the authority of the Ministry of Tourism, Resorts and Youth Policy of the KCR. Among the goals stated in the charter are "organizing tourist routes to places of archaeological sites on the territory of the republic, ... ensuring the integrity of the historical and architectural complex, historical environment and surrounding landscapes, promoting and popularizing the historical and cultural heritage and natural heritage of Karachay-Cherkessia in the tourist market of KarachaevoCircassian Republic, the Russian Federation and outside the Russian Federation "[31].

\section{Лumepamypa}

1. Алиев И. Не согрешайте ни милостью, ни жестокостью. // МК-Кавказ, 1-8 октября 2003 г.

2. Выписки из Единого государственного реестра прав на недвижимое имущество и сделок с ним. №№ 01/155/5011-513-518 от 01.09.2011

3. Джантеева Д. Возможна ли передача аланских храмов PПЦ?//URL: http://skfonews.info/article/108\&p=2\&c=1 Lfnf (Дата обращения 14. 02.2020)

4. Зайцева C. Вера и духовность взаимосвязаны. //Газета «День республики», 17 июля 2003 г.

5. Личный архив автора (далее - ЛАА). Выписка из протокола заседания комиссии при Президенте КЧР по экономическим и имущественным вопросам, г. Черкесск, 20 марта 2001 года.

6. ЛАА. Договор №2 «О сохранности и использовании недвижимого памятника истории и культуры религиозного назначения» г. Черкесск-п. Буково Зеленчукского района, 24 октября 1997 года.

7. ЛАА. Докладная записка «К проблеме передачи Зеленчукского, Сентинского и Шоанинского храмовых комплексов Русской Православной Церкви, 13 июля 2000 г.

8. ЛАА. Заключение Комиссии по вопросу использования Нижне-Архызского храмового комплекса, 20 февраля 2001 г.

9. ЛАА. Записка начальника ОПИК Р.Х. Боташева «Состояние и неотложные меры по устранению условий, способствующих правонарушениям в Нижне-Архызском фиилиале Карачаево-Черкесского историко-культурного музея-заповедника; Предложения главного специалиста Госинспекции по охране и использованию памятников КЧР Л.Л. Долечека.

10. ЛАА. Письмо Благочинного Православных церквей КЧР Василия Афонина к заместителю Председателя Правительства Р.Ф. А.Н. Шохину от 18.09 .92 на №1722п П41 от 26.08.92; Письмо Первого заместителя Председателя Совета Министров КЧР В.П. Редькина Заместителю Председателя Правительства РФ В.Ф. Шумейко от 22.04.93 на №1722п - П41 от 26.08.92. (проект) 
11.ЛАА. Письмо Благочинного Православных церквей КЧР Василия Афонина к заместителю Председателя Правительства РФ, председателю комиссии по вопросам религиозных объединений С.М. Шахраю «о передаче здания музея в пользование Карачаево-Черкесскому благочинию РПЦ [1994?]

12.ЛАА. Письмо Благочинного Православных Церквей КЧР, настоятеля Никольского собора протоиерея Валентина Корнеева Президенту КЧР Б.С. Эбзееву №80 от 15 мая 2009 г.

13. ЛАА. Письмо заместителя Председателя Государственного комитета РФ по управлению государственным имуществом В.П. Качанова в Совет Министров КЧР и Зеленчукский районный совет Народных депутатов №ОК-6/86007 от 21.12.93 «Поручение Правительства №ВШ-П36-30759 от 26 августа 1993 г., №ВШ-П36-38831 от 16 ноября 1993 г.»

14. ЛАА. Письмо Митрополита Гедеона заместителю Председателя правительства РФ В.Ф. Шумейко и Председателю Совета Министров КЧР В.И. Хубиеву, Председателю Комитет по свободе совести, вероисповеданиям, милосердию и благотворительности В.С. Полосину. (проект) [1992]

15. ЛАА. Письмо Митрополита Ставропольского и Владикавказского Гедеона заместителю Председателя правительства РФ В.Ф. Шумейко и Председателю Совета Министров КЧР В.И. Хубиеву №431 от 13 мая 1993 г.

16. ЛАА. Письмо Митрополита Ставропольского и Владикавказского Гедеона Председателю Совета Министров КЧР В.И. Хубиеву №405 от 13 апреля 1995 года.

17.ЛАА. Письмо Ответственного секретаря ВПМД Ставропольско-Бакинского региона священника Сергия Ильина и Секретаря Попечительского Совета ВПМД Ставропольско-Бакинского региона Ирины Лобковой в Карачаево-Черкесский Совет народных депутатов от 10.06.1991

18. ЛАА. Письмо Первого заместителя Председателя Совета Министров КЧР А.Г. Озова Председателю Совета Министров - Правительства РФ Черномырдину В.С. № 503-02 от 30.07.93 на №ВЧ-П36-15635 от 30.04.93

19. ЛАА. Письмо председателя Совета по делам религии Ю.П. Христораднова № 187 от 28.02.1991 в Исполнительный комитет Карачаево-Черкесского областного Совета народных депутатов [с приложением документов, определяющих и разъясняющих порядок регистрации уставов (положений) религиозных организаций, передачи им культовых (молитвенных) зданий и сооружений, другого имущества и земельных участков, а также инструкции Минфина СССР «О порядке налогообложения религиозных организаций»]

20. ЛАА. Письмо председателя черкесского отделения карачаевской демократической организации «Джамагат» К.И. Чомаева Председателю Верховного Совета КЧР В. Савельеву и Председателю Совета Министров КЧР В.И. Хубиеву №00/01 от 31 мая 1993 г.

21. ЛАА. Письмо президента Межрегиональной карачаевской ассоциации «Алан» А.А. Катчиева Президенту КЧР В.М. Семенову №6 о т 24.10.2000.

22. ЛАА. Письмо сотрудников штаб-квартиры ВПМД в Москве А. Гуськова, В. Чернышева, И. Соловьева Директору Карачаево-Черкесского историко-культурного и природного музея М.О. Байчоровой от 08.08.1991.

23. ЛАА. Письмо Уполномоченного по связям с религиозными организациями Н.Г. Проваторова Председателю Совета Министров КЧР В.И. Хубиеву «О проекте ответа В.С. Черномырдину на распоряжение Президента от 23.04.93 №281-рп».

24. ЛАА. Проект Письма заместителя Председателя Правительства Совета Министров КЧР А.Х. Татаршао Заместителю Министра культуры РФ М.Е. Швыдкому и Начальнику департамента по взаимодействию с Федеральным собранием и обществен- 
ными организациями В. Астапченко. «На №474-01-51/7-25 от 24.10.94 и №СШ-П-3631859 от 12.10 .94

25. ЛАА. Протокол встречи Президента КЧР В.М. Семенова с представителями РПЦ и руководством Министерства культуры КЧР по вопросу использования храмовых комплексов Карачаево-Черкесского музея-заповедника, 19 октября 2000 года.

26.ЛАА. Протокол заседания комиссии по вопросу использования храмов НижнеАрхызского комплекса Карачаево-Чекресского музея-заповедника, 6 февраля 2001 года.

27. ЛАА. Решение Малого Совета Зеленчукского районного Совета народных депутатов №5 от 06.11.91 «О ходатайстве православной общины п. Н. Архыз.

28. ЛАА. Служебная записка Министра культуры КЧР З.Б. Караевой на имя Главы КЧР В.М. Семенова «О проблеме храмовых комплексов Карачаево-Черкесского историко-культурного и природного музея-заповедника»; Записка Уполномоченного по связям с религиозными организациями Е.В. Кратова на имя Главы КЧР В.М. Семенова «О проблеме храмовых комплексов Карачаево-Черкесского историкокультурного и природного музея-заповедника»№1696-11 от 11.08.2000 На №580 от 02.08.2000.

29.Один из подожженных храмов выгорел полностью//URL: https://regnum.ru/news/polit/1342129.html (дата обр. 14.02.2020); В подожженном храме Карачаево-Черкесии пройдет массовое богослужение//URL: https://regnum.ru/news/polit/1400929.html (Дата обращения 14.02.2020)

30. Определение «О взаимоотношениях Церкви с государством и светским обществом на канонической территории Московского Патриархата в настоящее время». URL: https://mospat.ru/archive/page/sobors/1994-2/512.html (дата обращения 14.02.2020)

31.Устав Карачаево-Черкесского республиканского государственного учреждения «Аланский древнехристианский центр на Северном Кавказе», Черкесск, 2018 г.

\section{References}

1. Aliev I. Ne sogreshayte ni milostyu, ni zhestokostyu. [Do not sin either by mercy or cruelty]. MK-Kavkaz. 1-8 October. 2003 (In Russian).

2. Vypiski iz Yedinogo gosudarstvennogo reyestra prav na nedvizhimoye imushchestvo i sdelok s nim. [Extracts from the Unified State Register of Rights to Real Estate and Transactions Therewith]. No. 01/155/5011-513-518 from 09.01.2011 (In Russian).

3. Dzhanteeva $D$. Vozmozhna li peredacha alanskikh khramov RPTS? [Is it possible to transfer Alan churches to the Russian Orthodox Church?].

Available at: http://skfonews.info/article/108\&p=2\&c=1 (access date 14 February 2020) (In Russian).

4. Zaitseva S. Vera i dukhovnost vzaimosvyazany. Gazeta «Den respubliki». [Faith and spirituality are interconnected. Newspaper "Republic Day"]. 17.07.2003 (In Russian).

5. Lichnyy arkhiv avtora (daleye - LAA). Vypiska iz protokola zasedaniya komissii pri Prezidente KCHR po ekonomicheskim i imushchestvennym voprosam. [Personal archive of the author (hereinafter - LAA). Extract from the minutes of the meeting of the Commission under the President of the KCR on economic and property issues]. Cherkessk, 20/.03.2001 (In Russian).

6. LAA. Dogovor №2 «O sokhrannosti $i$ ispolzovanii nedvizhimogo pamyatnika istorii $i$ kul'tury religioznogo naznacheniya». g. Cherkessk-p. Bukovo Zelenchukskogo rayona. [Contract No. 2 "On the Preservation and Use of the Immovable Monument of History 
and Culture of Religious Purpose", Cherkessk-p. Bukovo Zelenchuksky district]. 24.10.1997 (In Russian).

7. LAA. Dokladnaya zapiska «K probleme peredachi Zelenchukskogo, Sentinskogo i Shoaninskogo khramovykh kompleksov Russkoy Pravoslavnoy Tserkvi. [Memorandum "On the Problem of the Transfer of Zelenchuksky, Sentinsky and Shoaninsky Temple Complexes of the Russian Orthodox Church]. 13.07.2000 (In Russian).

8. LAA. Zaklyucheniye Komissii po voprosu ispolzovaniya Nizhne-Arkhyzskogo khramovogo kompleksa. [Commission Opinion on the Use of the Lower Arkhyz Temple Complex]. 20.02.2001 (In Russian).

9. LAA. Zapiska nachalnika OPIK R.KH. Botasheva «Sostoyaniye i neotlozhnyye mery po ustraneniyu usloviy, sposobstvuyushchikh pravonarusheniyam v Nizhne-Arkhyzskom filiale Karachayevo-Cherkesskogo istoriko-kulturnogo muzeya-zapovednika; Predlozheniya glavnogo spetsialista Gosinspektsii po okhrane i ispolzovaniyu pamyatnikov KCHR L.L. Dolecheka. [Note by the Head of OPIC R.Kh. Botasheva "State and urgent measures to eliminate conditions conducive to offenses in the Lower Arkhyz branch of the Karachay-Cherkess historical and cultural museum-reserve; Proposals of the chief specialist of the State Inspectorate for the Protection and Use of Monuments of the KCR L.L. Dolecheka] (In Russian).

10. LAA. Pismo Blagochinnogo Pravoslavnykh tserkvey $\mathrm{KCHR}$ Vasiliya Afonina $k$ zamestitelyu Predsedatelya Pravitelstva RF A.N. Shokhinu ot 18.09 .92 na №1722p P41 ot 26.08.92; Pismo Pervogo zamestitelya Predsedatelya Soveta Ministrov KCHR V.P. Redkina Zamestitelyu Predsedatelya Pravitelstva RF V.F. Shumeyko ot 22.04.93 na №1722p - P41 ot 26.08.92. [Letter of the Dean of the Orthodox Churches of the KCR Vasily Afonin to the Deputy Prime Minister R.F. A.N. Shokhin from 09.18.92 at No. 1722p - P41 from 08.26.92; Letter of the First Deputy Chairman of the Council of Ministers of the KCR V.P. Redkin, Deputy Prime Minister V.F. Shumeyko from 04.22 .93 at No. 1722p - P41 from 08.26.92 (project)]. (In Russian).

11. LAA. Pismo Blagochinnogo Pravoslavnykh Tserkvey KCHR, nastoyatelya Nikolskogo sobora protoiyereya Valentina Korneyeva Prezidentu KCHR B.S. Ebzeyevu №80. [Letter from the Dean of the Orthodox Churches of the KCR Vasily Afonin to the Deputy Prime Minister of the Russian Federation, Chairman of the Commission on Religious Associations S.M. Shakhrai "on transferring the museum building for use to the KarachayCherkess deanery of the Russian Orthodox Church]. 1994 (In Russian).

12. LAA. Pismo Blagochinnogo Pravoslavnykh Tserkvey KCHR, nastoyatelya Nikolskogo sobora protoiyereya Valentina Korneyeva Prezidentu KCHR B.S. Ebzeyevu No. 80. [A letter from the Dean of the Orthodox Churches of the KCR, the rector of St. Nicholas Cathedral, Archpriest Valentin Korneev, to the President of the KCR, B.S. Ebzeev No. 80]. 15.05.2009 (In Russian).

13. LAA. Pismo zamestitelya Predsedatelya Gosudarstvennogo komiteta RF po upravleniyu gosudarstvennym imushchestvom V.P. Kachanova v Sovet Ministrov KCHR i Zelenchukskiy rayonnyy sovet Narodnykh deputatov No. OK-6/86007 ot 21.12.93 «Porucheniye Pravitelstva No. VSH-P36-30759 ot 26 avgusta 1993 g., №VSH-P36-38831 ot 16 noyabrya 1993 g. ». [Letter from the Deputy Chairman of the State Committee of the Russian Federation for State Property Management V.P. Kachanova to the Council of 
Ministers of the KCR and the Zelenchuksky District Council of People's Deputies No. OK-6/86007 dated 12.21.93 "Order of the Government No. VSh-P36-30759 dated 26.08.1993, No. VSh-P36-38831 dated 16.11.1993"] (In Russian).

14. LAA. Pismo Mitropolita Gedeona zamestitelyu Predsedatelya pravitelstva RF V.F. Shumeyko i Predsedatelyu Soveta Ministrov KCHR V.I. Khubiyevu, Predsedatelyu Komitet po svobode sovesti, veroispovedaniyam, miloserdiyu i blagotvoritelnosti V.S. Polosinu (proyekt). [Letter from Metropolitan Gideon to Deputy Prime Minister V.F. Shumeyko and Chairman of the Council of Ministers of the KCR V.I. Khubiev, Chairman of the Committee on Freedom of Conscience, Religion, Charity and Charity V.S. A strip. (project)]. 1992 (In Russian).

15. LAA. Pismo Mitropolita Stavropolskogo i Vladikavkazskogo Gedeona zamestitelyu Predsedatelya pravitelstva RF V.F. Shumeyko i Predsedatelyu Soveta Ministrov KCHR V.I. Khubiyevu No. 431. [Letter from Metropolitan of Stavropol and Vladikavkaz Gideon to Deputy Prime Minister V.F. Shumeyko and Chairman of the Council of Ministers of the KCR V.I. Khubiev No. 431]. 13.05.1993 (In Russian).

16. LAA. Pismo Mitropolita Stavropolskogo i Vladikavkazskogo Gedeona Predsedatelyu Soveta Ministrov KCHR V.I. Khubiyevu №405. [Letter from Metropolitan of Stavropol and Vladikavkaz Gideon to the Chairman of the KCR Council of Ministers V.I. Khubiev No. 405]. 13.04.1995 (In Russian).

17. LAA. Pismo Otvetstvennogo sekretarya VPMD Stavropolsko-Bakinskogo regiona svyashchennika Sergiya Ilina i Sekretarya Popechitelskogo Soveta VPMD StavropolskoBakinskogo regiona Iriny Lobkovoy v Karachayevo-Cherkesskiy Sovet narodnykh deputatov. [Letter from the Executive Secretary of the VPMD of the Stavropol-Baku Region Priest Sergiy Ilyin and Secretary of the Board of Trustees of the VPMD of the StavropolBaku Region Irina Lobkova to the Karachay-Cherkess Council of People's Deputies]. 10.06.1991 (In Russian).

18. LAA. Pismo Pervogo zamestitelya Predsedatelya Soveta Ministrov KCHR A.G. Ozova Predsedatelyu Soveta Ministrov - Pravitelstva RF Chernomyrdinu V.S. № 503-02 ot 30.07.93 na No. VCH-P36-15635 ot 30.04.93. [Letter of the First Deputy Chairman of the Council of Ministers of the KCR A.G. Ozov Chairman of the Council of Ministers - Government of the Russian Federation V. Chernomyrdin No. 503-02 dated 07.30.1993 at No. VCh-P36-15635 dated 30.04.1993] (In Russian).

19. LAA. Pismo predsedatelya Soveta po delam religii Yu.P. Khristoradnova No. 187 ot 28.02.1991 v Ispolnitelnyy komitet Karachayevo-Cherkesskogo oblastnogo Soveta narodnykh deputatov [s prilozheniyem dokumentov, opredelyayushchikh i razyasnyayushchikh poryadok registratsii ustavov (polozheniy) religioznykh organizatsiy, peredachi im kultovykh (molitvennykh) zdaniy i sooruzheniy, drugogo imushchestva i zemelnykh uchastkov, a takzhe instruktsii Minfina SSSR «O poryadke nalogooblozheniya religioznykh organizatsiy»]. [Letter from the Chairman of the Council for Religious Affairs Yu.P. Khristoradnova No.187 of 02.28.1991 to the Executive Committee of the Karachay-Cherkess Regional Council of People's Deputies [with the application of documents defining and explaining the procedure for registering charters (regulations) of religious organizations, transferring cult (prayer) buildings and structures, other property 
and land to them, as well as the instructions of the Ministry of Finance of the USSR "On the procedure for taxation of religious organizations"]. (In Russian).

20. LAA. Pismo predsedatelya cherkesskogo otdeleniya karachayevskoy demokraticheskoy organizatsii «Dzhamagat» K.I. Chomayeva Predsedatelyu Verkhovnogo Soveta KCHR V. Savelyevu i Predsedatelyu Soveta Ministrov KCHR V.I. Khubiyevu No. 00/01. [Letter from the Chairman of the Circassian Branch of the Karachay Democratic Organization "Jamagat" K.I. Chomaev, Chairman of the Supreme Council of the KCR, V. Savelyev, and Chairman of the Council of Ministers of the KCR, V.I. Khubiev No. 00/01]. 31.05.1993 (In Russian).

21. LAA. Pismo prezidenta Mezhregionalnoy karachayevskoy assotsiatsii «Alan» A.A. Katchiyeva Prezidentu KCHR V.M. Semenovu No. 6. [Letter from the President of the Inter-regional Karachai Association "Alan" A.A. Katchiev to the President of the KCR, V.M. Semenov No. 6]. 24.10.2000. (In Russian).

22. LAA. Pismo sotrudnikov shtab-kvartiry VPMD v Moskve A. Guskova, V. Chernysheva, I. Solovyeva Direktoru Karachayevo-Cherkesskogo istoriko-kulturnogo i prirodnogo muzeya M.O. Baychorovoy. [A letter from the staff of the VPMD headquarters in Moscow, A. Guskov, V. Chernyshev, I.Soloviev, to the Director of the M. Karachay-Cherkess Historical, Cultural and Natural Museum Baychorova]. 08.08.1991 (In Russian).

23. LAA. Pismo Upolnomochennogo po svyazyam s religioznymi organizatsiyami N.G. Provatorova Predsedatelyu Soveta Ministrov KCHR V.I. Khubiyevu «O proyekte otveta V.S. Chernomyrdinu na rasporyazheniye Prezidenta ot 23.04.93 No. 281-gr». [Letter of the Commissioner for Relations with Religious Organizations N.G. Provatorova V.I., Chairman of the Council of Ministers of the KCR Khubiev "On the draft response to V.S. Chernomyrdin at the disposal of the President of 04.23.93 No. 281-rp."]. (In Russian).

24. LAA. Proyekt Pisma zamestitelya Predsedatelya Pravitelstva Soveta Ministrov KCHR A.KH. Tatarshao Zamestitelyu Ministra kultury RF M.Ye. Shvydkomu i Nachal'niku departamenta po vzaimodeystviyu s Federalnym sobraniyem i obshchestvennymi organizatsiyami V. Astapchenko. «Na No. 474-01-51/7-25 ot 24.10.94 i No. SSH-P-36-31859. [Draft Letter of the Deputy Chairman of the Government of the Council of Ministers of the KCR A.Kh. Tatarshao to the Deputy Minister of Culture of the Russian Federation M.E. Shvydky and the Head of the Department for Cooperation with the Federal Assembly and Public Organizations V. Astapchenko. "At No. 474-01-51 / 7-25 of 10.24.94 and No. SSH-P-36-31859]. 12.10.94 (In Russian).

25. LAA. Protokol vstrechi Prezidenta KCHR V.M. Semenova s predstavitelyami RPTS i rukovodstvom Ministerstva kultury KCHR po voprosu ispolzovaniya khramovykh kompleksov Karachayevo-Cherkesskogo muzeya-zapovednika. [Protocol of the meeting of the President of the KCR, V.M. Semenov with representatives of the Russian Orthodox Church and the leadership of the Ministry of Culture of the KCR on the use of temple complexes of the Karachay-Cherkess Museum-Reserve]. 19.10.2000 (In Russian).

26. LAA. Protokol zasedaniya komissii po voprosu ispolzovaniya khramov NizhneArkhyzskogo kompleksa Karachayevo-Chekresskogo muzeya-zapovednika. [Protocol of the meeting of the commission on the use of temples of the Lower Arkhyz complex of the Karachay-Chekres museum-reserve]. 6.02.2001 (In Russian). 
27. LAA. Resheniye Malogo Soveta Zelenchukskogo rayonnogo Soveta narodnykh deputatov No. 5 ot 06.11 .91 «O khodataystve pravoslavnoy obshchiny p. N. Arkhyz. [Decision of the Small Council of the Zelenchuksky District Council of People's Deputies No. 5 of November 6, 91 "On the petition of the Orthodox community of the settlement of $\mathrm{N}$. Arkhyz.]. (In Russian).

28. LAA. Sluzhebnaya zapiska Ministra kultury KCHR Z.B. Karayevoy na imya Glavy KCHR V.M. Semenova «O probleme khramovykh kompleksov Karachayevo-Cherkesskogo istoriko-kul'turnogo i prirodnogo muzeya-zapovednika»; Zapiska Upolnomochennogo po svyazyam s religioznymi organizatsiyami Ye.V. Kratova na imya Glavy KCHR V.M. Semenova «O probleme khramovykh kompleksov Karachayevo-Cherkesskogo istorikokulturnogo i prirodnogo muzeya-zapovednika» No. 1696-11 ot 11.08.2000 Na No. 580 ot 02.08.2000. [Memorandum of the Minister of Culture of the KCR CR Z.B. Karaeva addressed to the Head of the KCR, V.M. Semenova "On the problem of temple complexes of the Karachay-Cherkess historical-cultural and natural museum-reserve"; Note by the Commissioner for Relations with Religious Organizations E.V. Kratov in the name of the Head of the KCR, V.M. Semenova "On the problem of temple complexes of the Karachay-Cherkess historical-cultural and natural Museum-Reserve" No.1696-11 of 08.11.2000 At No. 58 of 02.02.2000]. (In Russian).

29. Odin iz podozhzhennykh khramov vygorel polnostyu. [One of the set on fire churches burned out completely]. Available at: https://regnum.ru/news/polit/1342129.html (access date 14.02.2020); V podozhzhennom khrame Karachayevo-Cherkesii proydet massovoye bogosluzheniye. [Mass liturgy will take place in the set fire to the church]. URL: https://regnum.ru/news/polit/1400929.html (access date 14 February 2020) (In Russian).

30. Opredeleniye «O vzaimootnosheniyakh Tserkvi s gosudarstvom i svetskim obshchestvom na kanonicheskoy territorii Moskovskogo Patriarkhata $v$ nastoyashcheye vremya». [Opredeleniye «O vzaimootnosheniyakh Tserkvi s gosudarstvom i svetskim obshchestvom na kanonicheskoy territorii Moskovskogo Patriarkhata v nastoyashcheye vremya»]. Available at: https://mospat.ru/archive/page/sobors/1994-2/512.html (access date 14 February 2020) (In Russian).

31. Ustav Karachayevo-Cherkesskogo respublikanskogo gosudarstvennogo uchrezhdeniya «Alanskiy drevnekhristianskiy tsentr na Severnom Kavkaze». [The Charter of the Karachay-Cherkess Republican State Institution "Alan Ancient Christian Center in the North Caucasus"]. Cherkessk. 2018 (In Russian). 